\title{
A Survey of Archaeological, Architectural and Historical Sites on the San Antonio River from Olmos Dam to South Alamo Street and on San Pedro Creek from San Pedro Park to Guadalupe Street
}

Anne A. Fox

Follow this and additional works at: https://scholarworks.sfasu.edu/ita

Part of the American Material Culture Commons, Archaeological Anthropology Commons, Environmental Studies Commons, Other American Studies Commons, Other Arts and Humanities Commons, Other History of Art, Architecture, and Archaeology Commons, and the United States History Commons

Tell us how this article helped you.

This Article is brought to you for free and open access by the Center for Regional Heritage Research at SFA ScholarWorks. It has been accepted for inclusion in Index of Texas Archaeology: Open Access Gray Literature from the Lone Star State by an authorized editor of SFA ScholarWorks. For more information, please contact cdsscholarworks@sfasu.edu. 
A Survey of Archaeological, Architectural and Historical Sites on the San Antonio River from Olmos Dam to South Alamo Street and on San Pedro Creek from San Pedro Park to Guadalupe Street

Creative Commons License

(c) (1) (9)

This work is licensed under a Creative Commons Attribution-NonCommercial 4.0 International License 


\author{
A SURVEY OF \\ ARCHAEOLOGICAL, ARCHITECTURAL AND HISTORICAL SITES \\ ON THE SAN ANTONIO RIVER \\ FROM OLMOS DAM TO SOUTH ALAMO STREET \\ AND ON SAN PEDRO CREEK \\ FROM SAN PEDRO PARK TO GUADALUPE STREET
}

Anne A. Fox

Center for Archaeological Research The University of Texas at San Antonio

Archaeological Survey Report, No. 80

1979 
The preparation of this document was accomplished under Contract DACW63-79-M-0340 with the U.S. Army Corps of Engineers; Ft. Worth District, P. 0. Box 17300 , Ft. Worth, Texas 76102. 
TABLE OF CONTENTS

Page

Acknowledgments ....................... $i$...

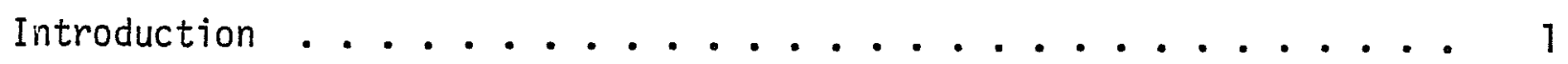

A Brief History of the Area ................ 2

Archaeological, Architectural and Historic Sites ......... 4

San Antonio River, 01mos Dam to IH 35 ............. 5

East Side of the River, IH 35 to the River Bend . . . . . . 7

West of the River, IH 35 to Navarro Street . . . . . . . 8

Between the River and San Pedro Creek, Navarro to Houston Street . . 8

Houston Street to Nueva Street.............. 9

East of San Pedro Creek, River Loop and Nueva Street to

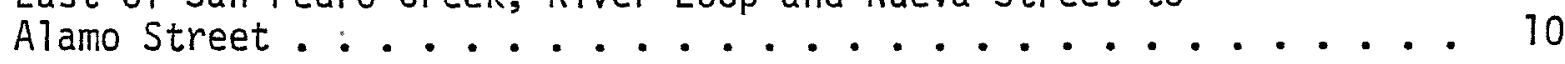

San Pedro Park to Houston Street . . . . . . . . . 11

West of San Pedro Creek, Houston Street to Durango Street . . . . 11

West of San Pedro Creek, Durango to Guadalupe . . . . . . . . 12

Summary and Conclusions ....................... 12

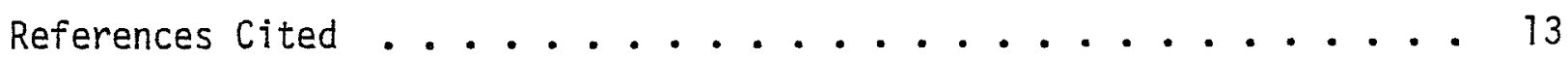





\section{ACKNOWLEDGMENTS}

Thanks are due to a number of people who helped in this effort. City Historic Preservation Officer Pat Osborne and her assistant Ysaac Cortez helped in identifying and dating sites and historic districts. Cecelia Steinfeldt of the Witte Museum also provided factual information. Center archaeologists Cristi Assad and James Ivey helped in numerous ways in the acquisition and compilation of site data. 


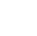




\section{INTRODUCTION}

In January 1979, the Center for Archaeological Research, The University of Texas at San Antonio, was requested by the Fort Worth District United States Army Corps of Engineers to prepare a historical, architectural and archaeological survey of the lands for 1/4-mile on either side of the San Antonio River from the 01mos Dam to South Alamo Street, and the San Pedro Creek from San Pedro Park to Guadalupe Street. The purpose of the project is to compile as much information as is now available on the prehistoric and historic sites located within the survey area for use in planning future flood control projects. The survey was carried out under the direction of $\mathrm{Dr}$. Thomas R. Hester, Director of the Center.

A team of three Center archaeologists worked together on this project: Cristi Assad and James Ivey carried out a field survey of areas which had not been covered by previous archaeological or historical surveys. Ivey also helped prepare the project map and assisted with numerous other details. Anne Fox compiled information from archeological survey reports, the Historic American Building Survey, the San Antonio Historic Survey (City Planning Department 1972) and various pubijcations on San Antonio history. This was combined with the results of the field survey to produce the final analysis of the project area.

Any discussion of the relative importance of historical and archaeological sites should begin by defining the selection criteria for inclusion of particular sites. For the purposes of this report, all prehistoric sites within the project area which have been recorded at the Texas Archeological Research Laboratory at Austin are indicated. The areas which have been systematically surveyed for archaeological sites include only the land from the southern boundary of Brackenridge Park to the 01mos Dam on the San Antonio River (Fox 1975 and Fox, Kleine and Katz 1979). From the park south on the river, the chance that there would be prehistoric sites still remaining is slim, considering the amount of channelization and other construction which has taken place. However, the possibility is always there and should be borne in mind during construction projects. The upper reaches of San Pedro Creek, especially the area within and just south of the park, should be intensively surveyed for evidence of prehistoric and historic sites. The amount of field work and research necessary to accomplish such a project puts it beyond the scope of this survey.

With respect to historic sites, a mass of data and field notes on construction of individual buildings has been collected during this survey and the related research. The field survey covered the area bounded by Ashby, Broadway, Alamo, 3rd, Quincy and IH 10. It was accomplished by two people driving slowly along each street and making copious notes on the neightorhood and on individual structures. No artifacts were collected. The area to the north of the survey had been rigorously studied previously (Fox 1975; Fox, Kleine and Katz 1979), and the area to the south is nearly a11 either included in historic districts or has been so completely aitered by recent construction as to make this sort of survey nonproductive.

No rigorous attempt has been made to develop a system for assigning relative importance to individual structures and sites. On the whole, the emphasis has been on locating and recording the earliest structures within a particular 

area, and assessing the approximate date of the structures which surround them. In this way one can trace the development of the city from earliest times. Sites within the project area which are on the National Register of Historic Places, as well as the boundaries of Historic Districts, are also indicated.

The locations of historic sites which were important in the history of the area but which are no longer visible above ground or have been covered by more recent construction are also noted. Since it is entirely possible that traces of these older structures may be present below the surface, these sites have been included in this report so that proper care will be taken in planned alterations to the river and creek channels.

\section{A BRIEF HISTORY OF THE AREA}

The significance of many of the sites included in this report can be understood through a look at the following brief history of San Antonio and the surrounding area.

Archaeological research in this area indicates that the San Antonio River valley has been inhabited since ca. 9000 B.C. Prehistoric peoples utilized open campsites on river terraces, chert workshops and/or quarry sites, burned rock middens, and rockshelters, primarily on or near stream valleys. Time periods represented range from Paleo-Indian (ca. 9200-6000 B.C.) to Late Prehistoric (ca. A.D. 1000 to 1600), with the majority of the sites occupied during the Archaic period (ca. 6000 B.C. to A.D. 1000). The Paleo-Indian period occupations are represented by the occurrence of Folsom, Plainview, Golondrina and other projectile points. The Archaic period peoples left a changing sequence of large projectile points and numerous types of stone tools. The Late Prehistoric period saw the introduction of the bow and arrow and the first simple types of pottery (Fox 1977:2).

These people appear to have been hunting and gathering groups who subsisted primarily on the game they could kill along with a wide assortment of nuts, fruits and other plant foods which were available. When the first Spanish explorers passed through the area in the late 17th century, they found a group of Indians whom they called the Payaya, who were living in much the same way as did their predecessors. They apparently were centered along the Medina River but came regularly to the San Antonio River basin in their search for food.

In May 1718, a Spanish expedition arrived at San Pedro Springs with the intention of relocating the Mission of San Antonio de Valero from the Rio Grande to the San Antonio River valley. A small temporary mission church was built about a mile below the springs on the west bank of San Pedro Creek. By 1724 this mission had moved to its present location on Alamo Plaza, just east of the project area.

Meanwhile, a presidio had been constructed in the vicinity of present Military plaza. In 1731 a group of settlers arrived from the Canary Islands. These people built homes and a church around the square which today is Main Plaza. At the same time, four additional missions were constructed down river from the 


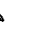


town, each ministering to a slightly different assortment of Indian groups recruited from the area between San Antonio and the coast. The Spaniards introduced cattle ranching and irrigated farming to the local scene, and built miles of acequias, or irrigation ditches, throughout the town and the surrounding countryside.

At first the settlement consisted of a group of flat-roofed stone and adobe buildings clustered around and to the north of Main and Military Plazas. Beginning in the 1820s, the newly independent Mexican government began to encourage immigration by granting impresario contracts to settle new areas between San Antonio and the coast. A few hardy Anglo-American adventurers and entrepreneurs came to live in San Antonio, bringing new ideas on commerce and architecture to the small Spanish town. However, constant pressure from raiding bands of Lipan and Comanche Indians caused the town to remain a small, tightly-settled enclave.

The steadily increasing number of Ang70-American immigrants joined forces with dissatisfied elements of the Mexican population to gain independence of Texas from Mexican rule in 1836. The numerous battles in and around the town took a dreadful toll in lives and property, and many of the inhabitants retreated temporarily to Mexico or to the United States, leaving San Antonio virtually deserted.

Once the fighting ceased and the general business climate improved, San Antonio received an influx of new settlers from the United States and from Europe. A steady stream of Germans and Alsatians began to arrive, bringing new types of architecture and new life styles to the rapidly-growing frontier town.

Texas' statehood in 1846 brought an increase in stability and safety to the town; the U.S. Army stationed troops there and soon made San Antonio the military headquarters for a large portion of Texas. The town began to grow and spread beyond its original confines, and new subdivisions appeared on the farmlands north of the Alamo. Still tied to rivers, creeks and acequias for water, settlement tended to string out north and south along the waterways. Buildings were constructed primarily of cut limestone from quarries at the head of the river, since timber had to be hauled in by wagon from East Texas or the coast and was too expensive to use other than as roof framing and flooring. Locallymade shingles were used on pitched roofs, taking the place of the flat earthen roofs and thatched roofs of the earlier Mexican structures. Two story homes and commercial buildings began to dominate the landscape in many parts of town, as the general character of San Antonio gradually changed from that of a sleepy Mexican village to a bustling commercial center. The waters of the San Antonio River were harnessed to turn numerous grist mills. Long trains of ox carts creaked their way between the port towns on the coast and San Antonio, then westward on the long, dusty trail to towns in northern Mexico.

The outbreak of the Civil War brought progress to a halt, and wartime shortages and the subsequent defeat of the Confederacy brought misery to the town's inhabitants. After the war, San Antonio was completely demoralized. One local observer wrote: 

Business was at its lowest ebb, there being no money to make improvements or keep the city clean. Real estate was a drag, its value destroyed by taxes... The streets at night were dark. The plazas during rainy weather were quagmires... (James 1938:94).

In 1866 came the crowning blow when hundreds of people, including many leading citizens, died in a cholera epidemic.

However, ranchers returning from the war found that in their absence their cattle had increased tremendously and herds of unbranded cattle roamed the open lands south of San Antonio. Rounding up and driving these animals to market brought sudden prosperity to this group, who spent freely of their newly acquired wealth in San Antonio. Local merchants quickly recovered and the town began to clean up and regain some of its lost momentum.

The arrival of the first railroad in 1877 began an era of rapid growth and development. Shipments of lumber could now be economically obtained. Lumber yards opened and frame houses became fashionable. Newly acquired weal th encouraged a spurt in home building which pushed the boundaries of San Antonio outward in all directions. New mercantile establishments and numerous other businesses were being created day and night, which called for a sudden increase in commercial building in the downtown area. Heusinger $(1951: 40)$ describes the city in 1880:

With a population of 20,550 as enumerated by the Federal Census, San Antonio with its many new commercial and manufacturing enterprises, newly constructed buildings and residences, military headquarters, attractive parks, the discovery of artesian wells resulting in an adequate water supply, a well equipped public school system and excellent private educational institutions, a reorganized Fire Department, and a new Post Office, now becomes a modern city.

Expanding continually as its population increased, San Antonio continued its growth and prosperity into the 20th century.

Sources consulted in the preparation of this historical background are: Campbe11 (1975), Fox (1975, 1977), Heusinger (1951), James (1938) and Ramsde11 (1976).

\section{ARCHAEOLOGICAL, ARCHITECTURAL AND HISTORIC SITES}

The numbers in the following commentary refer to sites and structures indicated on the enclosed maps of the project area. Information has been obtained from numerous sources. Where details are generally known or are found in several publications, no source is given. Structures which are on the National Register of Historic Places are indicated with an asterisk. The word "site" used in conjunction with the name of a structure indicates that it is no longer standing. 

Time did not allow survey or evaluation of individual structures within Historic Districts. It should be understood that each district includes many important structures not listed in this commentary. Some of these have been recorded by the Historic American Buildings Survey (HABS) and other local surveys, but many have never been officially recognized.

San Antonio River, 01mos Dam to IH 35 (Map \#1)

This is the only portion of the survey area which contains relatively unaltered open spaces; a number of prehistoric sites still remain. Two intensive archaeological and historical surveys have been carried out in this area, one of the 01 mos Basin between the dam and Hildebrand Avenue (Fox 1975), and one of Brackenridge Park (Fox, Kleine and Katz 1979).

1. 01mos Dam--built by the City after a major flood in 1921.

2. The Argyle Hotel--built as a ranch house by Charles Anderson in 1854 (Heusinger 1951:49) (HABS).

3. Alamo Heights--development begun in 1890; includes numerous large Victorian houses and more recent architectural styles.

4. Source of the River Archaeological District--includes both historic and prehistoric sites within the basin.

Sites 41 BX 291, 41 BX 21, 41 BX 290 and 41 BX 288 are prehistoric campsites. Surface collections in the general area suggest that these sites were probably intermittently occupied beginning about 9200 B.C. and continuing throughout the prehistoric era (Fox 1975:20).

Site 41 BX 286 is a prehistoric quarry/workshop.

Site 41 BX 282 is the San Antonio Spring, traditional source of the river.

Site $41 \mathrm{BX} 287$ is a possible historic house site.

Site 41 BX 285 contains mid-19th century house foundations.

Site 41 BX 284 appears to be an industrial site, possibly a grist mi17 known to be operating in the basin in 1858 (San Antonio Herald 1858).

Site 41 BX 283 is a limestone quarry, one of a group of quarries in operation here in the 19th century.

Site 41 BX 289 is the Brackenridge residence, constructed partially in 1852 and partial1y in 1886 (Sibley 1973:picture section).

5. George W. Brackenridge House--east wing built in 1852, west wing in 1886 (HABSL. 
6. Brackenridge Park--partially the original city grant, partially obtained through donation, purchase and condemnation. Development began in 1900 .

7. Upper Labor Acequia--constructed in 1777 (Minor and Steinberg 1968:9).

8. Alamo Madre Acequia--constructed ca. 1718 (ibid.).

9. Water Works Canal and Pumphouse--constructed in 1878 (Corner 1890:131).

10. San Antonio Zoo--construction begun in 1974.

11. Iron Truss Bridge--bui1t downtown in 1891, moved to the park in 1937.

12. Witte Museum--built in 1926 (Woolford and Quillin 1966:47).

13. Celso Navarro House--built ca. 1835, moved from Camaron Street in 1948 (Woolford and Quit1 in 1966:92).

14. John Twohig House--built in early 1840s, moved from St. Mary's Street in 1941 (HABS).

15. Francisco Ruiz House--said to date from 1745, moved from Dolores Street in 1943 (HABS).

16. Waterworks Canal--constructed ca. 1885.

17. 41 BX 170--ruins of Spanish-style lime kiln.

18. Alamo Portland and Roman Cement Works*--constructed in 1880 and moved away in 1908; kiln and several buildings remain (Baumberger n.d.) (HABS).

19. Kampmann House--mid-19th century stone house, sold to the City in 1916; vacant and in need of repair.

20. Zambrano House--small stone building, probabiy built in the early 1800 s on the family's original grant. More research should be done to substantiate this structure's background.

21. Jockey Club site--built ca. 1889, it was a two-story frame structure used as a club house. Horse racing on the adjoining track was discontinued in 1910, and the structure was razed in 1923 (San Antonio Light 1938).

22. Water Works Pumphouse--stone structure built in 1885, the building was used as a studio by noted sculptor John Gutzon Borglum from 1928 to 1937. Presently it is vacant and in need of repair.

With the exception of Alamo Heights and the two houses mentioned above, the majority of the housing in this portion of the study area peripheral to the park appears to have been built ca. 1900 and later. 
East Side of the River, IH 35 to the River Bend (Map \#2)

23. 01d Lone Star Brewery*--extensive late 19th century industrial complex, still in good condition; currentiy being renovated by the San Antonio Museum Association for an art museum.

24. Ford of "Los Texas"-historic river crossing (Cooley 1900:55).

25. Alamo Mi11s site and mi11 race--built in 1871; became the Crystal Ice and Manufacturing Company in 1877 (Morrison 1891:102); portions of the original buildings may remain.

River channelization in this area was part of the flood control project which resulted in the 01mos Dam.

26. Uhl or Charles Wurzbach House--this two-story stone house was built in 1876 (HABS).

27. Gustav Uhl House--a one-story stone house built ca. 1871. Other homes in this block appear to be from the same time period.

28. Thiele House--stone one-story home, built ca. 1850.

29. Thiele House--two-story brick house designed by J. Riley Gordon in 18901895 (HABS).

30. Irish Flat--the six or eight blocks north of the Alamo were first settled by Irish sutters and teamsters who came with the Army in 1846. This area became known as the Irish Flat (Ramsde11 1976:156). The homes described above are probably a part of that settiement.

This general area shows evidence of the gradual growth of the city northward. The simple early homes were surrounded and superseded by larger, more ornate brick and frame Victorian houses. In the 1880s the river bank became lined with commercial establishments, and many of the proprietors lived at or near their businesses, causing an intermingling of homes with commercial buildings.

31. Wolfson House--two-story brick Victorian house built ca. 1890.

32. Sullivan Carriage House*--designed by Alfred Giles, a stone structure built in 1896.

33. Municipal Auditorium--designed by Ayres, Wi11is and Jackson ca. 1930 (Hagner 1940:95). Burned 1979, she11 still standing.

34. Wil1iam Maverick House--home designed by Alfred Giles in 1893.

35. St. Mark's Episcopal Church--begun in 1858 (HABS).

36. Travis Park Methodist Church--begun in 1883, designed by Harvey Page. 
$$
\text { , }
$$ 
37. Majestic Theatre*--built ca. 1925.

38. 01d St. Mary's University--begun in 1852, recently converted into a hotel (HABS).

39. Alamo Plaza Historic District*--includes the site of Mission San Antonio de Valero and the historic area which surrounds it.

West of the River, IH 35 to Navarro Street (Map \#2)

40. Molino Blanco site--one of the first mills on the San Antonio River, this one was in operation by 1835 . No detailed information on its history is available.

41. Dr. Claudius E. R. King House--stone, one-story house designed by ATfred Gijes in 1880.

Other houses in the immediate area west of Augusta Street are similar, one-story Victorian houses. Commerical development is dense between St. Mary's street and the river.

Between the River and San Pedro Creek, Navarro to Houston Street (Map \#2)

This is the northern section of the old town and was the first industrial area in the early 19th century. For this reason, structures of all ages and descriptions exist side by side, and some buildings have known many uses and frequent remodeling.

42. Ursuline Academy*--built in 1851, with additions to 1882 . Recently renovated for use as a craft center.

43. San Pedro Acequia--this stone-lined channel is still present beneath the surface under buildings and streets throughout the center of town (Fox 1978a, 1978b).

44. Laux Mi11 site--now covered by the Milam Building, this 5-story stone mi11 was built in the 1860s and continued in operation until the late 19th century (Steinfeldt 1978:84).

45. One-story stone house reputed to date from ca. 1850.

46. One-story stone house which mày date from 1800 .

47. Two-story stone building which appears to have been built in the $1860 \mathrm{~s}$.

48. 01d Presbyterian Church (Ramsde11 1976:124)--begun in 1860, designed by Theodore Giraud (San Antonio Express 1879). Much remodeled, this building is now used as a bar. The architecture of the rear portion still betrays its original purpose. 

Much more concentrated study of each individual building in this area is urgently needed. Archival and architectural studies should be done of all properties containing older structures, and protection given to those worthy of preservation.

\section{Houston Street to Nueva Street (Map \#2)}

This was the original town of San Antonio de Bexar. Some very old structures remain as part of later reconstructions and remodeling, but the 18th century town has for the most part been displaced by 1860 to 1900 commercial buildings, many of which have in turn been replaced by newer structures and parking lots. Some of the more important sites are listed here, but the list is in no way complete. Here, also, a concentrated program of recording and research is needed.

49. Main-Military Plaza Historic District-Military Plaza was begun in 1722 when an adobe presidio was constructed by the Spanish. Main Plaza was begun in 1731 by the Canary Island settlers.

50. Spanish Governor's Palace*--built in 1749 as a residence for the Presidial Captain. This building was reconstructed by Harvey Smith in 1931 (Fox $1977: 1)$

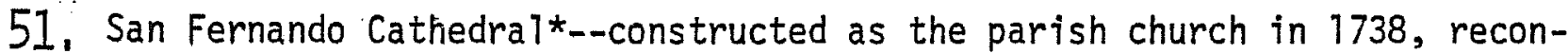
structed and remodeled numerous times, most recently in 1978.

52. Vogel Belt Complex*--block of late 19th century stores, recently renovated.

53. Bexar County Court House*--built in 1891-96, J. Riely Gordon, architect (HABS).

54. 41 BX 483--Rio Rita Cistern, bui1t in 1ate 19th century, excavated by CAR in 1978 (McGraw and Valdez 1979), remains as a feature of a new restaurant.

55. First National Bank*--built in 1886 (Ramsde11 1976:125).

56. Building designed for William Maverick by Alfred Giles in 1883-1884. The rest of this block of stores dates from the same period.

57. Block of stores built in 1876-1878.

58. Lewis Mill site--this mi11 was built in 1845 and continued in operation through most of the 19th century. It was dismantled in 1890 (Steinfeldt 1978:84).

59. Site 41 BX 334-336--19th century house foundations, tested by CAR 1978 (Fox 1978b).

60. Wolfson's store--designed by Alfred Giles in 1880 (HABS).

The river in the downtown area has been developed into a park, with landscaping, walks, shops and restaurants. The installation of a cutoff 

channel and control gates, and elimination of two sharp bends below the center of town, have helped control flooding. A number of old iron truss bridges are sti11 in use, most of them constructed in 1890 and 1891 . A study should be done of bridges on the river.

East of San Pedro Creek, River Loop and Nueva Street to Alamo Street (Map \#2)

61. La Villita Historic District*--probably first settled in the early 19th century by Spaniards connected with military units stationed at the Alamo, the area became a small village after the flood of 1819 when many people moved in and built solid stone houses among the earlier adobe houses. Much of this area has been restored.

62. Alamo Madre Acequia (41 BX 8)--section excavated by Witte Museum in 1966 (Schuetz 1970) and restored for Hemisfair.

63. Dashie11 House--bui1t ca, 1850 (HABSL.

64. Cos House--buitt before 1835 (HABS).

65, 41 BX 369/Gresser House--tested by CAR 1978 (Ivey 1978b).

66. 41 BX 329/Dolores A7drete House-m-tested by CAR 1978 (Fox, Valdez and Bobbitt 1978).

67. German-EngTish Schoo1--founded 1859 (Steinfeldt 1978:146).

68. Pajalache or Concepcion Acequia--ca. 1729 to 1869 (Minor and Steinberg 1968:8), still present beneath the ground.

69. Site 41 BX 303--Group of 19th century houses tested by CAR 1978 (Katz 1978), now covered by or incorporated into Hotel Plaza Nacional.

70. King William Historic District*--from the 1860 s to 1880 s this area was predominantly inhabited by German families who built elaborate houses, many of which have been restored and are still used as residences. Many of these houses have been recorded by HABS; some are on the National Register.

71, 41 BX 326/Mayer House site--tested by CAR 1978 (Ivey 1978a).

72. Anton Wulff House--tested by Texas Historical Commission 1974 (Clark 1974).

73. Pioneer Flour Mill--on the site of the first mi11 built by Carl H. Guenther in 1858 (Schuchard 1951:5[.

74. Guenther's Upper Mill site--the second mi11 built by Guenther in 1868 (ibid.:22). Site appears to be relatively undisturbed and the mi17's foundations are undoubtedly still present beneath the ground surface. Mill wheel housing foundations are still visible in river bed. 


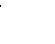


75. U.S. Arsenal*--the United States Government acquired 16 acres on South Flores Street and began construction in 1859 (Heusinger 1951:27).

76. Commanding Officer's House--built in 1859 with later additions, has just been renovated by the City (Fox 1978).

San Pedro Park to Houston Street (Map \#2)

77. San Pedro Springs Park*--traditional site of the first settlement of San Antonio, this has long been a public park. The springs are the source of San Pedro Creek, and prehistoric camp sites were once visible throughout the area around the springs (C. D. Orchard, personal communication). The area was extensively developed as an amusement center for late 19th century San Antonio. No historical or archaeological surveys have been done in this section.

78. Stone Building--ca. 1850 or earlier.

79. Alazan Acequia site--designed by Francois Giraud in 1872, completed in 1876 (Fox 1978:11-12), sti11 present, stone 1ined, underground.

The houses in the area to the west of the park are small, one-story frame buildings, built primarily in the 1890 to 1920 period.

The creek has been channelized through most of this area.

80. Frank Walsh House--built ca. 1860. At one time North Flores Street, which paralleled the San Pedro Acequia, was lined with modest homes and lush gardens. This is an example of the type of house found there in the 1870s.

Most of these homes are now in a state of rapid decline, and part of the area is currently being bulldozed.

The area just west of the expressway has been extensively cleared and is now being redeveloped. Unfortunately, no archaeological survey was done at any time during this activity, and very few structures survived the bulldozer.

81. Chapel of Miracles--a sma11, private chapel, said to be located near the original site of Mission San Antonio de Valero (Ramsdell 1976:176).

82. San Francisco de Paola--buitt in 1927 (Hagner 1940:101).

83, 41 BX 484/Menger Soap Works*--a though the company began operations in 1851, this substantial stone building was not constructed until 1862 (Ivey 1979).

West of San Pedro Creek, Houston Street to Durango Street (Map \#2)

The creek has been channelized through this area. 

This was the original Mexican Town during the 19th and early 20th centuries, the San Antonio equivalent of "the other side of the tracks." Urban renewal has now el iminated most of the blighted areas which eventualiy developed there. A few of the older structures have been salvaged and restored.

84. The 01d Market--buildings constructed in the last half of the 19th century have recently been renovated and become El Mercado, with shops and restaurants.

85. Navarro House*--property of the Texas Parks \& Wild1ife Department, built $\mathrm{ca}$. 1850. The one- and two-story buildings in this complex have been restored and are open to the pubtic.

West of San Pedro Creek, Durango to Guadalupe (Map \#2)

The creek is channelized through this section.

Homes west of the expressway appear to have been built primarily in the 1870 to 1900 period. Most of the area is badly deteriorated.

86. Jose Antonio Navarro Elementary School*--built in 1885, one of the oldest public schools still standing in San Antonio.

87. One-story home built in 1870 , typical of the area.

The land between the expressway and the creek has been cleared and redeveloped into a commercial district by the San Antonio Development Agency.

\section{SUMMARY AND CONCLUSIONS}

San Antonio is fortunate to have a rich and varied history, which is reflected in the numerous historic and prehistoric sites and structures which are still present in the area. Since water is an essential need of man, for thousands of years the San Antonio River and the San Pedro Creek have drawn people to live on their banks. Each group has left tangible evidence of its presence in the soil, on the landscape and in the cultural heritage of the city. Changes which are planned for the waterways should take into consideration the historic and prehistoric sites which would be affected, and should make provisions to preserve as much as possible of this evidence of San Antonio's history.

of the lands included in the survey area, thorough prehistoric and historic surveys have been conducted in only a comparatively small section at the upper end of the San Antonio River. A major effort is needed to systematically locate, research and record historic sites, especially in the older sections of the city. Criteria should be established for gauging the relative importance of structures in order to decide where conservation efforts should be concentrated. Since such an undertaking is beyond the scope of this project, it is strongly recommended that the City of San Antonio initiate such a project in the near future. 


\section{REFERENCES CITED}

Baumberger, $C$.

n.d. Some History of Early Pioneer Days of the Cement Industry in West Texas. Text of a speech, date and occasion unknown. Files of Ellen S. Quillin Library, Witte Museum.

Campbe11, T. N.

1975 The Payaya Indians of Southern Texas. Southern Texas Archaeological Association, Special Publication 1.

Clark, J. W., Jr.

1974 Preliminary Archeological Excavations at Wulff House, San Antonio, Texas. Texas Historical Commission, office of the State Archeologist, Special Report 14.

Cooley, E. B.

1900 A Retrospect of San Antonio. Texas Historical Association quarterly IV:54-56.

Corner, W.

1890 San Antonio de Bexar. Bainbridge and Corner, San Antonio.

Fox, A. A.

1975 An Archaeological Assessment of the Southern Portion of the 01mos Basin, Bexar County, Texas. Center for Archaeological Research, The university of Texas at San Antonio, Archaeological Survey Report 9.

1977 An Archaeological Assessment of the San Antonio 201 Wastewater Treatment Project. Center for Archaeological Research, The University of Texas at San Antonio, Archaeological Survey Report 41 .

1978a Archaeological Investigations of Portions of the San Pedro and Alazan Acequias in San Antonio, Texas. Center for Archaeological Research. The University of Texas at San Antonio, Archaeological Survey Report 49.

1978b Preliminary Archaeological Assessment of South Parking Lot Area (Phase I) Site of Courthouse Annex, San Antonio, Texas. Letter Report to Bexar County Commissioners' Court, October. 

Fox A. A., S. Kleine and S. Katz

1979 Archaeological and Historical Assessment of Brackenridge Park, City of San Antonio. Manuscript in preparation. Center for Archaeological Research. The University of Texas at San Antonio, Archaeological Survey Report 33.

Fox, D. E., F. Valdez, Jr. and L. O. Bobbitt

1978 An Archaeological Assessment of the Dolores Aldrete House Property, San Antonio, Texas. Center for Archaeological Research. The University of Texas at San Antonio, Archaeological Survey Report 58.

Fox, D. E., D. Scurlock and J. W. Clark, Jr.

1977 Archaeological Excavations at San Fernando Cathedral, San Antonio, Texas: A Preliminary Report. Texas Historical Commission, Office of the State Archeologist, Special Report 22.

Hagner, L. M.

1940 Alluring San Antonio. Naylor, San Antonio.

Heusinger, E. W.

1951 A Chronology of Events in San Antonio. Standard Printing Company, San Antonio.

Ivey, J. E.

1978a Archaeological Investigations at the Mayer House (41 BX 326), San Antonio, Texas. Center for Archaeological Research, The University of Texas at San Antonio, Archaeological Survey Report 59.

1978b Archaeological Investigations at the Gresser House (41 BX 369), San Antonio, Texas. Center for Archaeological Research, The University of Texas at San Antonio, Archaeological Survey Report 60.

1979 Historical and Archaeological Investigations at the Menger Soap Works (47. BX 484), San Antonio, Texas. Center for Archaeological Research, The University of Texas at San Antonio, Archaeological Survey Report 79.

James, V. L.

1938 Frontier and Pioneer Recollections of Early Days in San Antonio and west Texas. Artes Graficas, San Antonio. 

Katz, P. R:

1978 Archaeological and Historical Assessment of the Arciniega Street Area, San Antonio, Texas. Center for Archaeological Research, The University of Texas at San Antonio, Archaeological Survey Report 61.

McGraw, A. J. and F. Valdez, Jr.

1979 Rio Rita: An Historical Cistern in Downtown San Antonio. Center for Archaeological Research, The University of Texas at San Antonio, Archaeological Survey Report 57.

Minor, J. E. and M. L. Steinberg

1968 A Brief on the Acequias of San Antonio. The San Antonio Branch of the Texas Section, American Society of Civil Engineers.

Morrison, A.

1891 The City of San Antonio, Texas. George W. Engelhardt \& Co., St. Louis.

0'Nei11, Perez, Lance, Larcade, Architects

1972 San Antonio Historic Survey. City of San Antonio, City Planning Department.

Ramsde17, C.

1976 San Antonio, A Historical and Pictorial Guide. Revised by Carmen

Perry. University of Texas Press.

San Antonio Express

1879 First Presbyterian History. November 30.

San Antonio Herald

1858 Advertisement for E. P. Alsbury Mi11. September 29.

San Antonio Light

1938 S. A. Racing at High Level in Gay Nineties. June 5.

Schuchard, E.

1951 100th Anniversary, Pioneer Flour Mi11s, San Antonio, Texas, 18511951. Naylor, San Antonio. 

Sibley, M. M.

1973 George w. Brackenridge, Maverick Philanthropist. University of Texas Press.

Steinfeldt, C.

1978 San Antonio was. San Antonio Muesum Association.

Schuetz, M. K.

1970 Excavation of a Section of the Acequia Madre in Bexar County, Texas, and Archeological Investigations at Mission San Jose in Apri1, 1968. Texas Historical Survey Committee, Archeological Report 19.

Woolford, B. C. and E. S. Quitlin

1966 The Story of the Witte Memorial Museum, 1922-1960. San Antonio Museum Association. 

This page has been

redacted because it

contains restricted

information. 

This page has been

redacted because it

contains restricted

information. 
